\title{
Digitālā dienaskārtība un publiskā diplomātija Latvijā
}

\author{
MA Soc. Pol. Silvestrs Savickis \\ Rìgas Stradiña universitāte \\ silvestrs.savickis@lead.lv
}

\section{Kopsavilkums}

Publiskā diplomātija ieṇem aizvien nozīmīgāku lomu pasaules valstu ārpolitikā. Informācijas tehnologiju attīstība un sociālo tīklu popularitātes straujais pieaugums liek diplomātiem izmantot modernos informācijas kanālus publiskās diplomātijas un ārpolitikas mērḳu sasniegšanai. Sociālo tīklu izmantošanas efektivitāti iespējams izmērìt, noskaidrojot diplomātu spēju veidot vēlamo dienaskārtību digitālajā vidē, kas arī ir šī raksta mērkis.

Publikācijā aplūkota Latvijas Ārlietu ministrijas spēja veidot digitālo dienaskārtību publiskās diplomātijas laukā. Šì publikācija ir plašāka pētījuma sastāvdaḷa, kura ietvaros tika analizēti trīs Baltijas valstu Ārlietu ministriju oficiālo Facebook kontu ieraksti 2019. gadā. Pielietojot Oksfordas Universitātes digitālās diplomātijas pētnieku izstrādāto metodolog̣iju, tika analizēts, kādas ir katras valsts publiskās diplomātijas prioritātes digitālajā vidē, kā arī publikas reakcijas un iesaistes apjoms, reagèejot uz šīm prioritātēm.

Pētījuma rezultāts ḷāva pierādìt, ka Latvijas Ārlietu ministrija spēj veidot digitālo dienaskārtību, un vienlaikus rosināja diskusiju, kā arī izgaismoja jaunus aspektus digitālās diplomātijas pētniecības laukā.

Atslēgvārdi: digitālā diplomātija, jaunā publiskā diplomātija, sociālie tīkli, e-pārvalde.

\section{levads}

Šĩ pētījuma objekts ir tradicionālās diplomātijas paveids - publiskā diplomātija. Kā uzskata Lundas Universitātes profesors un publiskās diplomātijas pētnieks Džeimss Paments (James Pamment), 21. gadsimta publiskās diplomātijas ietekme ir konceptualizējama trīs veidos: pirmkārt, publiskā diplomātija tiek balstīta uz pienēemumu, ka sabiedrībā 
pastāv konkrētas ietekmīgas grupas jeb elites, ko publiskās diplomātijas aktoriem - ārlietu ministrijām, vēstniecībām vai starptautiskajām organizācijām - vajadzētu ietekmēt. Otrkārt, publiskās diplomātijas aktivitātēm ir jābūt veidotām tā, lai tās mērḳtiecīgi ietekmētu šo grupu viedokḷus, uzskatus un uzvedību. Treškārt, būtu sagaidāms, ka šīs elites savukārt ietekmētu savu valdību politiku [6, 6-8]. Tādējādi valstu publiskajai diplomātijai ir jāveicina publikas atbalsts virzītajai dienaskārtībai un jāsekmē savas valsts ārpolitikas mērḳu sasniegšana.

Vienlaikus uz mūsdienu politiskās skatuves aizvien lielāku lomu ieṇem informācijas komunikāciju tehnologijas. Izṇēmums nav arī starptautiskā politika, starptautiskās attiecības un diplomātija. Digitālās diplomātijas pētnieki apgalvo, ka tieši informācijas komunikāciju tehnolog̣ijas ir atvieglojušas komunikāciju starp ārlietu ministrijām un diplomātiem, kā arī ārlietu ministrijām un vietējiem iedzīvotājiem [13], tādējādi acīmredzami sniedzot norādi uz informācijas komunikāciju tehnologiju ietekmi arī publiskās diplomātijas laukā.

Diplomātijas virsuzdevums ir realizēt savas valsts ārpolitiku, izmantojot savā arsenālā esošos instrumentus - gan tradicionālos, kā divpusējās tikšanās, oficiālā sarakste un publiskās uzstāšanās, gan tos, kas kḷuvuši par diplomātijas instrumentiem, pateicoties informācijas komunikāciju tehnologiiju ienākšanai politikas norisēs un sabiedrības pieprasījumam pēc to izmantošanas arì tradicionāli noslēgtajā un bieži noslēpumainajā diplomātijas pasaulē.

Lai saprastu minēto politikas realizācijas instrumentu efektivitāti, ir nepieciešami mērījumi un metodologiijas to veikšanai. Digitālās platformas spēj piedāvāt instrumentārijus mērījumiem, lai iegūtu nepieciešamos datus, savukārt nozares pētnieki ir izstrādājuši metodolog̣ijas, lai mērījumu ceḷā iegūtos rezultātus izvērtētu un interpretētu.

Šis pētījums tika veiks, lai izanalizètu trīs Baltijas valstu - Lietuvas, Latvijas un Igaunijas - aktivitātes digitālajā vidē un novērtētu to efektivitāti, izmantojot vienu no pētnieku piedāvātajām dimensijām sociālo tīklu ietekmes novērtēšanai publiskās diplomātijas mērḳiem - digitālās dienaskārtības veidošanu. Darbs uzskatāms par inovatīvu, jo salīdzinoši pētījumi par Baltijas valstu Ārlietu ministriju digitālo diplomātiju sociālajos tīklos līdz šim nav tikuši veikti.

\section{Sociālo mediju loma publiskajā diplomātijā}

Mūsdienās ārpolitika un arī diplomātija ir kḷuvusi par kompleksas pasaules sastāvdaļu, kas ietver attiecību veidošanu ekonomikas, kultūras, izglītības un zinātnes, tautsaimniecības, tirdzniecības un visās citās dzīves jomās. Tāpēc diplomātijas nozares pētnieki aizvien vairāk pievērš uzmanību diplomātijas pārmaiṇu procesiem [3], tostarp publiskajai diplomātijai kā atsevišķam diplomātijas paveidam. 
Klingendāles Starptautisko attiecību institūta diplomātijas studiju pētnieks Jans Melisens (Jan Melissen) darbā The New Public Diplomacy: Between Theory and Practice (“Jaunā publiskā diplomātija: starp teoriju un praksi") [5, 11] raksta:

\begin{abstract}
"Pasaule, kurā publiskā diplomātija tika uzskatīta par pārpalikumu no diplomātiskā dialoga, strauji izzūd. [..] Lai izprastu jauno publisko diplomātiju, ir bezjēdzīgi paḷauties gan uz diplomātijas vēsturiskajiem tēliem (kas joprojām prevalē lielā daḷā diplomātijas studiju literatūras), gan arī nav ieteicams veikt vēstures prakses tālāku projekciju mūsdienu starptautiskajā vidē (gadījumā, ja publiskā diplomātija tiek saprasta kā tradicionāla propaganda). Jaunā publiskā diplomātija kḷūs par pieaugošu standarta komponenti diplomātiskajā praksē [..]."
\end{abstract}

Melisens ieviesa arī jaunu terminu - "jaunā publiskā diplomātija”. Viṇš to raksturoja kā tādu, kas koncentrējas uz saikni ar tìklotām vai saistītām (connected) publikām, pārejot no monologa uz dialogu, iesaistīšanos un ilgtermiña attiecību veidošanu [5, 3-27]. Savukārt cits publiskās diplomātijas lauka pētnieks Nikolass Kulls (Nicholas Cull) jauno publisko diplomātiju raksturoja kā procesu, ar kura palīdzību starptautiskie aktori cenšas sasniegt savus ārpolitikas mērķus, iesaistot ārvalstu publiku [12, 31-54].

Sociālo mediju izmantošana diplomātijas laukā ir nosaukta par transformatīvo attīstību (transformative development) starptautiskajā politikā [7; 8]. To ienākšana diplomātijā ir ḷâvusi ne tikai izmainīt hierarhiju diplomātiskajā vidē, bet arī vienkāršos cilvēkus dziḷāk iesaistīt politikas procesu vērošanā un devusi tiem iespēju publiski izteikties par šiem procesiem. Digitālā diplomātija un sociālie tỉkli kā diplomātijas lauka sastāvdaḷas ir radijjuši iespējas jaunu un praktisku jēdzienu "publiskā diplomātija" un "maigā vara" paplašināšanai, būvējot pamatus, uz kuriem valstu valdỉbas veido platformas savu nāciju zìmola veidošanai (nation branding) [1].

Digitālās diplomātijas pētnieki, cenšoties noskaidrot atbildes uz jautājumu, cik efektīvi ir sociālie mediji publiskās diplomātijas mērḳu sasniegšanai, izvirza trīs dimensijas, ko sociālie mediji ienes publiskās diplomātijas laukā, un tās ir [2, 74-75]:

1) digitālās dienaskārtības veidošana (digital agenda-setting);

2) digitālās klātbūtnes palielināšana (digital presence-expansion);

3) digitālo sarunu veidošana (digital conversation-generating).

Katra dimensija raksturo būtiskus ietekmes aspektus: vēstījuma saturu, informācijas sasniedzamību, auditorijas iesaisti un tās noskaņojumu.

Pirmā dimensija ir digitālās dienaskārtības veidošana. Izmantojot sociālo tīklu platformas, diplomāti veido diskusiju dienaskārtību, kas paredzēta izraudzītajām mērḳa auditorijām. Termina "digitālās dienaskārtības veidošana" izcelsme ir saistìta ar komunikācijas zinātnē lietoto dienaskārtības veidošanas teoriju [17], kurā teikts, ka plašsaziņas lìdzekḷi, veidojot ziṇu sniegšanas secību un prioritātes, ietekmē sabiedrības viedokli par to vai citu notikumu svarīgumu, tādējādi nosakot, par ko cilvēkiem jādomā un kā cilvēkiem vajadzētu domāt. Šeit aplūkotās dienaskārtības veidotāji ir nevis plašsaziṇas līdzekḷi, bet diplomāti, kuri, veidojot ierakstus un uzsākot sarunu sociālajos tīklos, veido dienaskārtību sevis izvēlētajām mērḳa auditorijām. 
Publiskajā diplomātijā galvenais uzdevums un centrālais elements vienmēr ir bijusi informācijas izplatǐ̌sana. Jaunajā publiskajā diplomātijā informācijas nodošana ir priekšnosacījums mijiedarbībai un sarunas uzsākšanai, jo patiess dialogs ir iespējams tikai tad, ja abas puses ir iepazinušas sarunas tēmu, tām ir lïdzīga sapratne un kopīga interese par aplūkojamo jautājumu [2, 74]. Publiskā diplomātija palīdz veidot noteiktu valsts tēlu ārvalstu auditorijās caur rūpīgi atlasītām ziṇām un vēstījumiem, vēršot auditoriju uzmanību un izcel̦ot tās tēmas, ko valsts vēlas izcelt, un minimizējot tās tēmas, par kurām valsts nevēlas runāt. Diplomāti, regulāri un mērḳtiecīgi pasniedzot kādu informāciju savos sociālo tīklu kontos, var radìt iespaidu par to kā svarīgu un vērtīgu, kam būtu vērts pievērst uzmanību. Salīdzinot ar tradicionālajiem plašsaziṇas līdzekḷiem, sociālajiem medijiem ir lielākas iespējas "noḳert virsrakstus" jeb piesaistìt auditorijas uzmanību, pateicoties to iespējām aptvert lielu auditoriju, publicēšanas regularitātei un ātrumam, lietojamībai un ilglaicīgumam [10].

Otrā dimensija ir digitālās klātbūtnes palielināšana jeb diplomātu klātbūtnes apjoms sociālajos medijos. Tas nozīmē, ka tiek fiksēts diplomātu ierakstu daudzums laika posmā, to pārpublicēšanas reizes, lasītāju komentāri un emocijzīmju pievienošana ierakstam.

Savukārt trešã un pēdējā dimensija ir digitālo sarunu veidošana. Tieši šajā dimensijā uzmanība tiek fokusēta uz kvalitatīvo klātbūtni sociālajos tīklos. Auditorijas iesaistǐšana ir viens no visaugstāk vērtētajiem elementiem jaunajā publiskajā diplomātijā [2, 75]. Laba publiskā diplomātija vairs nevar būt balstīta uz monologiem, bet tā jāveido uz dialoga principiem. Tai jāsekmē divvirzienu vai pat daudzvirzienu (multidirectional) komunikācija ar mērḳi veicināt sadarbības iniciatīvas [11]. Divvirzienu komunikācija l̦auj diplomātiem koncentrēt uzmanību uz viṇu dienaskārtību, mazināt dezinformāciju un veicināt savstarpējo sapratni. Tieši šì īpašã iezīme ar sociālo mediju palīdzỉbu l̦auj realizēt publiskās diplomātijas mērḳus citādi nekā ar tradicionālajām metodēm [2, 71-88].

\section{Digitālās dienaskārtības vispārīgs raksturojums un loma publiskajā diplomātijā}

Viena no trim dimensijām jaunajā publiskajā diplomātijā jeb digitālajā publiskajā diplomātijā ir diplomātisko aktoru spēja veidot digitālo dienaskārtību. Izmantojot Bjolas, Jianga [2, 71-78] un Manora [16] izstrādāto modeli, šì darba autors veica pētījumu un analizēja ārlietu dienesta spēju veidot digitālo dienaskārtību digitālajā vidē.

Dienaskārtības veidošana, vispārīgi definējot, ir nozīmīguma piešḳiršana tām vai citām tēmām, jautājumiem vai problēmām sabiedrības dienaskārtībā [18], un šì prerogatīva tradicionāli ir piederējusi plašsaziņas līdzekḷiem.

Digitālajā laikmetā veidot dienaskārtību ir iespējams ikvienam indivīdam, organizācijai vai valstij, pateicoties sociālo tīklu pieejamībai un popularitātei. Arī ārlietu ministrijas var mēǵināt veidot sev vēlamu dienaskārtỉbu, izmantojot sociālo tỉklu platformas un sarunājoties ar digitālo sabiedrību, izcelt un popularizēt, diskutēt un atkārtoti 
rosināt sarunu, veidot ierakstus par valsti, pozitīvā gaismā atspogulojot tēmas, piemēram, par ekonomiku vai kultūru, un mazināt diskusiju intensitāti par tēmām, kas publiskās diplomātijas kontekstā valstij nav vēlamas, piemēram, iekšpolitiskām nesaskaṇām vai pretrunīgu ārpolitiku.

Digitālās dienaskārtības veidošanai ārlietu dienesti izmanto un var izmantot visplašāko iespējamo digitālo platformu un tīklu spektru. Piemēram, ASV Valsts departaments komunikācijai digitālajā vidē izmanto blogu vietni un piecus populārākos sociālos tìklus - Twitter, Facebook, YouTube, Flickr un Instagram, kā arī papildus nosauktajiem uztur un darbojas vēl septiņos Twitter kontos svešvalodās - arābu, farsi, spāṇu, franču, portugāḷ, krievu un urdu valodā [19].

Publiskās diplomātijas pētījuma vajadzībām tika izmantots sociālais tīkls Facebook, jo tā ir platforma, kuras izmantošana veicina ilgtermiṇa attiecību veidošanu un uzturēšanu ar digitālo publiku, savukārt digitālās diplomātijas nolūkos citkārt analizētā mikroblogošanas vietne Twitter vairāk piemērota informācijas ievākšanai un viedokḷa popularizēšanai $[14 ; 15]$, un attiecību veidošanai ar elitēm $[4,15]$.

\section{Spējas veidot digitālo dienaskārtību novērtēšanas metodoloǵija}

Lai novērtētu digitālās dienaskārtības veidošanas spēju, autors balstijiās uz iepriekšminēto Bjolas, Janga un Manora piedāvāto metodolog̣iju, kas aprakstīta turpinājumā. Analīzei tika izmantots Latvijas Ārlietu ministrijas oficiālo Facebook konts angḷu valodā (ministrija uztur divas atseviškłas Facebook kontus - latviešu un angḷu valodā).

Pirmkārt, pēc nejaušības metodes tika atlasīti gandrīz 100 ieraksti Latvijas Ārlietu ministrijas laika joslā Facebook sociālajā tīklā par visu pētāmo laika periodu, t. i., 2019. gadu. Tie bija vidēji astoṇi ieraksti katrā kalendārajā mēnesī, kas tikuši veikti tikai darba dienās ar intervālu no divām līdz četrām dienām un pēc algoritma: pirmdiena ceturtdiena - otrdiena - piektdiena - pirmdiena - trešdiena - otrdiena - piektdiena. Izvēlētajā dienā tika fiksēts tas ieraksts, kas bija izpelnījies lielāko publikas uzmanību jeb saṇēmis visvairāk "patīk" vai citas emocijzīmes. Šāds algoritms radīja iespēju vienmērīgi novērtēt Ārlietu ministrijas aktivitāti un ierakstu saturu, neanalizējot pilnīgi visus ierakstus, kā arī potenciāli turpināt pētījumu, salīdzinot Latvijas Ārlietu ministrijas un citu valstu diplomātisko dienestu aktivitātes.

Otrkārt, veicot ierakstu kontentanalīzi, tie tika sagrupēti pa kategorijām, vienā kategorijā apvienojot ierakstus ar līdzīgu saturu un mērḳi [9, 6626-6628]. (1. tabulā ir atspoguḷoti tematu kategorizācijas piemēri.)

Treškārt, ja konkrētām tēmu kategorijām Ārlietu ministrija Facebook kontā veltījusi vairāk nekā $10 \%$ no kopējiem ministrijas ierakstiem, tie tiek fiksēti kā ministrijas ieskatā prioritāri un ir paredzēti mērḳa publikai jeb veido ministrijas digitālo dienaskārtību Facebook sociālajā tīklā. Citiem vārdiem, tās tēmu kategorijas, par kurām ministrija ir runājusi visvairāk, veido tās digitālo dienaskārtību. 
1. tabula. Tematu kategorizācijas piemēri

\begin{tabular}{|c|c|c|}
\hline Kategorija & Temata apraksts & Piemērs \\
\hline $\begin{array}{l}\text { Divpusējās } \\
\text { attiecības }\end{array}$ & $\begin{array}{l}\text { Raksta par jautājumiem, kas saistīti ar notikumiem } \\
\text { vai vēstījumiem par divpusējām attiecībām ar } \\
\text { valstīm, t. sk. vēstulēm, apsveikumiem, vēstnieku } \\
\text { akreditācijām un vizītēm. }\end{array}$ & $\begin{array}{l}\text { Oficiālā vizītē viesojas } \\
\text { sabiedroto valsts } \\
\text { premjerministrs. }\end{array}$ \\
\hline $\begin{array}{l}\text { Daudzpusējās } \\
\text { attiecības }\end{array}$ & $\begin{array}{l}\text { Raksta par jautājumiem, kas saistīti ar notikumiem } \\
\text { vai vēstījumiem par daudzpusējiem jautājumiem: } \\
\text { darbību starptautiskās organizācijās, piemēram, } \\
\text { NATO, ES, EDSO, OECD, un globālajiem tematiem: } \\
\text { klimata pārmaiṇu, kosmosa izpēti u. c. }\end{array}$ & $\begin{array}{l}\text { lestājas par konvencijas } \\
\text { apstiprināšanu. }\end{array}$ \\
\hline $\begin{array}{l}\text { Vēstures } \\
\text { jautājumi }\end{array}$ & $\begin{array}{l}\text { Raksta par jautājumiem, kas saistīti ar notikumiem vai } \\
\text { vēstijjumiem par būtiskiem notikumiem valsts vēsturē, } \\
\text { slaveniem cilvēkiem, piemiṇas un svinību dienām. }\end{array}$ & $\begin{array}{l}\text { Šogad atzīmēta 30. gadskārta } \\
\text { kopš atbrīvošanās no } \\
\text { komunistu jūga. }\end{array}$ \\
\hline $\begin{array}{l}\text { Ekonomikas } \\
\text { izaugsme }\end{array}$ & $\begin{array}{l}\text { Raksta par jautājumiem, kas saistīti ar notikumiem vai } \\
\text { vēstijumiem par valsts ekonomikas sasniegumiem vai } \\
\text { izmaiṇām, t. sk. uzṇēmējdarbību. }\end{array}$ & $\begin{array}{l}\text { Valsts kopējais nacionālais } \\
\text { produkts otrajā ceturksnī } \\
\text { pieaudzis par } 0,5 \% .\end{array}$ \\
\hline $\begin{array}{l}\text { Diasporas } \\
\text { aktualitātes }\end{array}$ & $\begin{array}{l}\text { Raksta par jautājumiem, kas saistīti ar notikumiem } \\
\text { vai vēstījumiem par ārvalstīs dzīvojošo diasporu, tai } \\
\text { svarīgiem notikumiem un norisēm. }\end{array}$ & $\begin{array}{l}\text { Diasporas namā uzstāsies } \\
\text { ievērojamais dzimtenes } \\
\text { dzejnieks. }\end{array}$ \\
\hline
\end{tabular}

Ceturtkārt, nākamais solis spējas veidot digitālo dienaskārtību novērtēšanā ir digitālās publikas jeb lasitāju reakcijas uz diplomātu ierakstiem fiksācija un uzskaite. Veidojot ierakstus sociālajā tīklā, tiek pieṇemts, ka publika:

1) ritinot savu laika joslu (scrolling timeline), apstājas un piefiksē tematu, par ko ir veikts ieraksts;

2) izlasa ierakstu, apskata attēlu vai noskatās video;

3) ja ieraksta saturs izraisa emocijas un vēlmi reageèt, tad:

a) tam spiež pogu (aktualizē iespēju) "patīk" vai citu emocijzīmi;

b) to komentē;

c) ar to dalās savā laikajoslā, tādējādi padarot pieejamu arī saviem (citiem) sekotājiem.

Iepriekšminētās rīcības tiek dēvētas par publikas iesaisti (engagement), un tie ieraksti, kuriem summāri ir vislielākais iesaistes gadỉjumu skaits, tiek uzskatìti par populārākajiem un ar lielāku komunikatīvo pienesumu, nekā tie ieraksti, kam šīs publikas iesaistes ir mazāk vai pat nav nemaz.

Piektkārt, tiek matemātiski izrēḳināts kopējais publikas vidējais iesaistes apjoms (A) laika posmā, ko aprēķina, izdalot kopējo publikas iesaistes gadijjumu skaitu (B) ar kopējo veikto ierakstu skaitu (C):

$$
\mathrm{A}=\mathrm{B}: \mathrm{C},
$$

kur A - publikas vidējais iesaistes apjoms izvēlētajā laika posmā;

B - kopējais publikas iesaistes gadījumu skaits izvēlētajā laika posmā;

C - kopējais veikto ierakstu skaits izvēlētajā laika posmā. 
Visbeidzot, tās tēmu kategorijas, kurās publikas iesaiste ir virs vidējā apjoma (A), publika ir atzinusi par saistošākām un apliecina interesi par tām. Savukārt tās tēmu kategorijas, kurās publikas iesaiste ir zem vidējā apjoma (A), ir tai mazāk saistošas un interesantas.

Lai novērtētu Ārlietu ministrijas spēju veidot digitālo dienaskārtību, ir jāsakrīt gan tēmu kategorijām, ko ministrija ir izvēelējusies ietvert savā digitālajā dienaskārtībā (ierakstu tematika), gan tām tēmu kategorijām, kurās publikas iesaiste ir virs vidējā apjoma (publikas iesaiste: "patīk" vai citas reakcijas, dalīšanās un komentāri). Ja minētie lielumi sakrīt, tad var uzskatīt, ka ārlietu dienests spēj veidot savu digitālo dienaskārtību, ja nesakrìt, - nespēj.

Kā uzskata Oksfordas Universitātes digitālās diplomātijas pētnieks Ilans Manors (Ilan Manor), saskañā ar piedāvāto metodolog̣iju tās tēmas, kas saṇem digitālās publikas iesaisti virs vidējā apjoma, šì publika atzīst par saistošām, par tām ir vieglāk uzsākt sarunu ar sekotājiem, veidot dialogu un dialogisko iesaistǐšanos, iespējams gūt atbalstu ārpolitiskajām nostādnēm un vēstījumiem [4, 198]. Tādējādi iespējams gan identificēt tēmas, kuras gūst atbalstu un ir uzskatāmas par veiksmīgām digitālajā dienaskārtībā, gan arī kopumā novērtēt ārlietu dienesta spēju veidot digitālo dienaskārtību.

\section{Latvijas Ārlietu ministrijas spēja veidot digitālo dienaskārtību un tās raksturojums}

Kopumā 2019. gadā sociālajā tīklā Facebook Ārlietu ministrija publicējusi 576 ierakstus, kas, matemātiski rēḳinot, vidēji ir 48 ieraksti mēnesī jeb 1,55 ieraksti dienā. Latvijas Ārlietu ministrija uztur divus Facebook kontus - angḷu un latviešu valodā. Šì pētījuma nolūkiem tika izmantota ministrijas konts anglu valodā, jo publiskās diplomātijas mērḳa publika ir ārvalstu elites un sabiedrība kopumā, ko ministrija cenšas uzrunāt, lietojot tieši šo kontu.

Saskaņā ar izvēlēto metodologiiju analizējot Latvijas Ārlietu ministrijas ierakstus sociālajā tīklā Facebook, pēc kontentanalīzes tika konstatēts, ka veiktie gandrīz 100 ieraksti saturiski atbilst 6 no 11 kategorijām jeb tēmu blokiem. Ministrijas raksti lielākoties iekḷaujami divos tēmu blokos - "divpusējās attiecības ar citu valsti" un "daudzpusējās attiecības un darbība starptautiskajās organizācijās". Abus tēmu blokus veido 86 ieraksti no kopumā 99 pētījumā ietvertajiem ierakstiem jeb $85 \%$.

No pētījumā iekḷautajiem 99 ierakstiem 54 ir piekritīgi kategorijai "divpusējās attiecības ar citu valsti”. Tajos Latvijas Ārlietu ministrija runā par oficiālo pozīciju attiecībās ar kaimiṇvalsti Krieviju, demokrātijas procesu atbalstu Venecuēlai, bezvīzu režìmu, Latvijas pilsoṇiem, kas ieceḷo Uzbekistānā, divpusējām vizītēm, Latvijas un citu valstu oficiālo amatpersonu tikšanos, abpusējām vēstnieku akreditācijām, apsveikumiem valstu neatkarības dienās un nacionālajos svētkos. Minētajā kategorijā skaitliski dominē ziņas par Latvijas vēstnieku akreditāciju ārvalstīs. 
Otrā dominējošā tēmu kategorija ir "daudzpusējās attiecības un darbība starptautiskajās organizācijās”. Tajā 32 no 99 ierakstiem Latvijas Ārlietu ministrija runā par diplomātu un amatpersonu dalību daudzpusējos forumos, piemēram, ES Vispārējo lietu padomē, ES un Arābu valstu pirmajā samitā Ėgiptē, par Baltijas Jūras valstu padomes sanāksmi Rīgā. Tāpat ministrija digitālajā dienaskārtībā izvirza jautājumus par dalību un aktivitātēm ES Austrumu partnerības programmā, starptautisko organizāciju, kā NATO, ES un OECD, amatpersonu vizìtēm un tikšanos ar Latvijas partneriem.

Deviñi ieraksti attiecas uz kategoriju "vēstures jautājumi, valsts simboli un lepnums par valsti”, divi - "jautājumi un notikumi, kas skar ārzemēs dzīvojošo diasporu”, savukārt viens ieraksts saistīts ar tēmu "tūrisma dimensija jeb valsts kā pievilcīgs ceḷojumu galamērḳis" un viens ar tēmu "iekšpolitiskie jautājumi". Neviens ieraksts neatbilda piecām kategorijām, kurās aplūkoti sasniegumi ekonomikā, kultūrā un zinātnē, sportā, runāts par izcilām personībām valstī un konsulārajiem jautājumiem.

Tādējādi 10\% no kopējā ierakstu skaita aplūkotajā laika posmā pārsniedza abas dominējošās tēmu kategorijas, kas ietver ierakstus par valsts ārpolitikas divpusējiem un daudzpusējiem jautājumiem. Saskaņā ar izmantoto metodologiju tikai šīs divas kategorijas veido Latvijas Ārlietu ministrijas digitālo dienaskārtỉbu. Abas kategorijas ir guvušas publikas ievērību, pārsniedzot vidējo iesaistes rādītāju Latvijas Ārlietu ministrijas Facebook kontā, tādējādi apliecinot ministrijas spēju veidot digitālo dienaskārtību.

\section{Secinājumi}

Saskaņā ar pētỉjuma rezultātiem tika gūts apstiprinājums Latvijas Ārlietu ministrijas spējai veidot digitālo dienaskārtību. Saskaṇā ar piedāvāto metodolog̣iju tās tēmas, kas saṇēma publikas iesaisti virs vidējā apjoma, digitālā publika atzina par saistošām, tātad par tām ir vieglāk uzsākt sarunu ar sekotājiem, veidot dialogu un dialog̣isko iesaistīšanos, iespējams gūt atbalstu ārpolitiskajām nostādnēm un vēstījumiem [4, 198]. Tādējādi iespējams gan identificēt tēmas, kuras gūst atbalstu un uzskatāmas par veiksmīgām digitālajā dienaskārtībā, gan arī kopumā novērtēt ārlietu dienesta spēju veidot digitālo dienaskārtību.

Tomēr pastāv vēl viens būtisks fakts, kura ietekme šajā pētỉjumā netika vērtēta. Ievērojami lielāku publikas atsaucību ir guvusi ierakstu kategorija "vēstures jautājumi, valsts simboli un lepnums par valsti”, kur, lai arī pētījuma ietvarā atbilstoši metodologijai ietverti vien devinini ieraksti, publikas iesaistes vidējais apjoms ir 98, kas ir teju trīs reizes lielāka nekā publikas iesaiste, reagéjot uz Ārlietu ministrijas veidotās digitālās dienaskārtības tēmām.

Minētais parāda, ka Latvijas Ārlietu ministrijas veidotā digitālā dienaskārtība atšķiras no tās dienaskārtības, ko gaida publika - ministrijas Facebook konta sekotāji. Ja Ārlietu ministrija izvēlas akcentēt savu darbību divpusējo un daudzpusējo attiecību jomā, tad publikas uzmanību un atbalstu gūst ar valsts vēsturi, simboliem un lepnumu saistīti ieraksti. Tādējādi digitālās diplomātijas (un ne tikai) pētniekiem vajadzētu 
turpināt analizēt, kādu iespaidu uz publiskās diplomātijas mērḳiem atstāj situācija, kad ārlietu dienests un publika izvēlas atšḳirīgus prioritārus jautājumus, kurus iekḷaut dienaskārtībā.

\section{Digital Agenda Setting and Public Diplomacy of Latvia}

\section{Abstract}

Public diplomacy plays an increasingly important role in the foreign policy of countries around the world. The development of information technologies and the rapid rise in the popularity of social networks motivate diplomats to use modern information channels to achieve public diplomacy and foreign policy objectives. The effectiveness of the use of social networks can be measured by clarifying the ability of diplomats to set the desired agenda in the digital environment, which is also the aim of this study.

This article looks at digital agenda setting ability of the Ministry of Foreign Affairs of Latvia in the field of public diplomacy. It is a part of a broader study where the posts on official Facebook accounts of the Ministries of Foreign Affairs of the Baltic States in 2019 were specifically analysed. The methodology developed by the researchers of digital diplomacy at Oxford University was used to analyse the priorities of each country's public diplomacy in the digital environment and the extent of public response and engagement in response to these priorities.

The results of the study demonstrated the digital agenda setting ability of MFA of Latvia, while encouraging discussion and highlighting new aspects in the field of research of digital diplomacy.

Keywords: digital diplomacy, new public diplomacy, social networks, e-government.

\section{Avoti un literatūra}

\section{Literatūra}

1. Aronczyk, M. 2013. Branding the Nation: The Global Business of National Identity. Oxford: Oxford University Press.

2. Bjola, C., Jiang, L. 2015. Social media and public diplomacy: A comparative analysis of the digital diplomatic strategies of the EU, US and Japan in China. In: C. Bjola \& M. Holmes (Eds.). Digital diplomacy theory and practice. Oxon: Routledge.

3. Hocking, B., Melissen, J., Riordan, S., Sharp, P. 2012. Futures for Diplomacy: Integrative Diplomacy in the 21st Century. Clingendael Report Nr. 1.

4. Manor, I. 2019. The Digitalization of Public Diplomacy. Cham (Switzerland): Palgrave Macmillan.

5. Melissen, J. 2005. The New Public Diplomacy: Soft Power in International Relations. New York: Palgrave Macmillan. 
6. Pamment, J. 2013. New Public Diplomacy in the 21st Century: A Comparative Study of Policy and Practice. Routledge New Diplomacy Studies. London: Rutledge.

7. Reynolds, A., McCombs, M. E. 2002. News Influence on Our Pictures of the World. Media effects. Abingdon: Routledge. 11-28.

8. Seib, P. 2012. Real-time Diplomacy: Politics and Power in the Social Media Era. New York: Pallgrave, Macmillan.

9. Stein, J. G. 2011. Diplomacy in the Digital Age: Essays in Honour of Ambassador Allan Gotlieb. Plattsburg. New York: McCelland \& Stewart.

\section{Vārdnīcas un enciklopēdijas}

10. Clarke, V., Braun, V. 2014. Thematic analysis. In: Encyclopedia of quality of life and well-being research. Springer: Dordrecht.

\section{Raksti akadēmiskos žurnālos}

11. Agichtein, E., Castillo, C., Donato, D., Gionis, A., Mishne, G. 2008. Finding High Quality Content in Social Media. In Proceedings of the 2008 International Conference on Web Search and Data Mining. Ed by M. Najork. New York: ACM, 183-194.

12. Cowan, G., Arsenault, A. 2008. Moving from Monologue to Dialogue to Collaboration: Three Layers of Public Diplomacy. The ANNALS of the American Academy of Political and Social Science. 616(1).

13. Cull, N. 2008. Public diplomacy: Taxonomies and histories. The Annals of the American Academy of Political and Social Science. 616(1).

14. Hanson, F. 2012. Revolution @State: The Spread of Ediplomacy. Lowy Institute for International Policy, $34 \mathrm{p}$.

15. Hughes, D. J., Rowe, M., Batey, M., Lee, A. 2012. A tale of two sites: Twitter vs. Facebook and the personality predictors of social media usage. Computers in Human Behaviour. 28(2), 561-569.

16. Kwak, H., Lee, C., Park, H., Moon, S. 2010. What is Twitter, a social network or a News media? Proceedings of the 19th international conference on world wide web, 591-600.

17. Manor, I. 2017. America's selfie - Three years later. Place Branding and Public Diplomacy. 13(4), 308-324.

18. McCombs, M. E., Shaw, D. L. 1972. The agenda-setting function of mass media. Public Opinion Quarterly.36(2), 176.

\section{Interneta resursi}

19. U.S. Department of State. https://www.state.gov/about-us-office-of-global-social-media/ 